\title{
LETTERS
}

\section{Public trust in the information age}

We are at a crossroads in medicine, and in science in general. In a Humanities article published in CMAJ, Dr. Maya Goldenberg ${ }^{1}$ uses vaccine hesitancy as an example of the erosion of public trust in medicine. Mistrust is the hidden force that may stand between us and our patients. Dr. Goldenberg suggests that we must be more transparent, embrace the uncertainty that lies at the heart of medicine and avoid ties with industry that might threaten trust. I agree and would add that we cannot rebuild trust without acknowledging why mistrust exists, nor move forward without addressing the changing nature of health literacy in the information age.

Public trust allows us to encourage healthy behaviours and to respond to public health crises. ${ }^{2}$ Building trust requires us to acknowledge times when we as a profession have got things very wrong. Along with the great triumphs of medicine, such as the eradication of smallpox, we carry heavy historical baggage, including disgraceful practices such as the purposeful mistreatment of Inuit people with tuberculosis (as recently acknowledged by the Office of the Prime Minister of Canada ${ }^{3}$ ).

Threats to public trust continue today, not only with questionable relationships between medicine and the pharmaceutical industry, but also with recent high-profile cases of privacy violations; for example, the case of health care workers inappropriately accessing private health information of the late Rob Ford, former Mayor of Toronto, ${ }^{4}$ and episodes of inappropriate access of private data by health care workers in Nova Scotia $^{5}$ and other unethical practices. Accepting historical wrongdoing as well as addressing ongoing ethically problematic behaviour is essential to rebuilding trust.

I agree with Dr. Goldenberg that more information alone isn't the solution. The role of the Internet and "Dr. Google" cannot be understated, as increasing patient dissatisfaction is associated with greater use of and greater reliance on online searches rather than medical professionals. ${ }^{6}$ Even the most well educated may lack tools for critically appraising the information with which they're presented, with opinion and anecdote being held in the same regard as methodologically sound research. Unfortunately, false information is also more quickly spread online than true information, ${ }^{7}$ and it is easy to overestimate one's level of knowledge after only superficial exposure to information. ${ }^{8}$ Supporting patients in how they acquire and interpret information is an important role for physicians and other medical professionals in the information age.

Dr. Goldenberg raises an important point about the role of public trust in the practice of medicine. It is essential for us all to be aware that our role as physicians includes not only providing advice and treatment, but also acknowledging the limitations of medicine and supporting our patients as they become increasingly active partners in their care.

\section{Jennifer M. Bryan MD MSPH}

Assistant professor, Division of Emergency Medicine, Department of Medicine, University of Toronto, Toronto, Ont.
Cite as: CMAJ 2019 August 12;191:E899. doi: $10.1503 / \mathrm{cmaj} .72514$

\section{References}

1. Goldenberg MJ. Vaccines, values and science. CMAJ 2019;191:E397-8.

2. Lynch T. [Re]building trust (Summary paper). Philadelphia: American Board of Internal Medicine (ABIM) Foundation; 2018. Available: https:// abimfoundation.org/wp-content/uploads/2018/ 10/2018-ABIM-Foundation-Forum-Summary.pdf (accessed 2019 Apr. 14).

3. Trudeau J. Statement of apology on behalf of the Government of Canada to Inuit for the management of the tuberculosis epidemic from the 1940s-1960s [speech, Iqaluit (NU): 2019 Mar. 8.] Ottawa: Office of the Prime Minister of Canada; 2019. Available: https://pm.gc.ca/en/news/ speeches/2019/03/08/statement-apology-behalf -government-canada-inuit-management-tuberculosis (accessed 2019 July 25).

4. Warren M. Hospital workers convicted for snooping into Rob Ford's personal health files. The Toronto Star 2016 May 6. Available: www.thestar.com/news/gta/2016/05/06/hospital -workers-convicted-for-snooping-into-rob-fords -personal-health-files.html (accessed 2019 July 25).

5. The Canadian Press. Hundreds of N.S. patient records accessed in "substantial" privacy breach. CTV News [updated 2017 Aug. 31]. Available: www.ctvnews.ca/canada/hundreds-of-n-s -patient-records-accessed-in-substantial-privacy -breach-1.3506915 (accessed 2019 July 25).

6. Hou, J, Minsun, S. The role of provider-patient communication and trust in online sources in Internet use for health-related activities. J Health Commun 2010; 15(Suppl 3):186-99.

7. Vosoughi S, Roy D, Aral S. The spread of true and false news online. Science 2018;359:1146-51.

8. Anspach NM, Jennings JT, Arceneaux K. A little bit of knowledge: Facebook's news feed and selfperceptions of knowledge. Research \& Politics 2019;6:1-9. doi: 10.1177/2053168018816189.

Competing interests: None declared. 